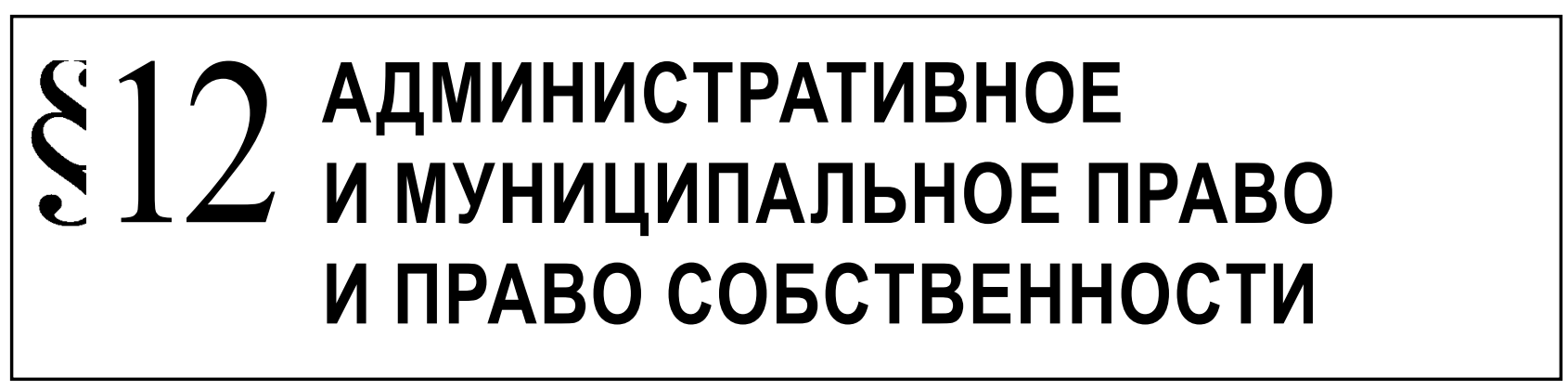

Клейменова М.О.

\title{
К ВОПРОСУ ОБ АДМИНИСТРАТИВНО-ПРАВОВОМ РЕГУЛИРОВАНИИ ЗАЩИТЫ ИСКЛЮЧИТЕЛЬНОГО ПРАВА НА СРЕДСТВА ИНДИВИДУАЛИЗАЦИИ
}

Аннотация: Предметом исследования являются нормы законодательства, осуществляющие государственное регулирование по обеспечению административно-правового режима фирменного наименования и других средств индивидуализации товаров, работ и услуг (товарного знака и знака обслуживания). В качестве предмета исследования выступают доктринальные положения административного, гражданского и информационного права, практика реализации административно-правовых методов государственного регулирования по обеспечению защиты средств индивидуализации юридических лиц, товаров, работ и услуг, таких как фирменное наименование, товарный знак и знак обслуживания. Методологическую основу составляют совокупность методов научного познания, среди которых ведущее место занимает диалектико-материалистический метод познания.Метод системного анализа позволил определить место средств индивидуализации в системе исключительных прав, существующих в праве. Научная новизна состоит в комплексном общеправовом анализе особенностей административно-правового регулирования защиты средств индивидуализации. Рассмотрено законодательное регулирование административно-правовых методов по обеспечению режима правообладателей средств индивидуализации; рассмотрен регистрационный режим средств индивидуализации; определены административные способы защиты исключительного права на фирменное наименование, товарный знак и знак обслуживания, а также выявлены виды административной ответственности за правонарушения исключительного права на средство индивидуализации.

Ключевые слова: административно-правовое регулирование, защита, средства индивидуализации, фрирменное наименование, товарный знак, знак обслуживания, исключительные права, регистрационные действия, административное законодательство, правоприменительная практика.

A ктивно развивающиеся в Российской Федерации предпринимательские отношения высветили ряд серьезных проблем, которые требуют своего решения в науке административного права. Они, в частности, касаются:

- процесса создания и функционирования средств индивидуализации юридических лиц, товаров, работ и услуг;

- регистрационного режима фирменного наименования, товарного знака и знака обслуживания;

- полномочий и юридической ответственности правообладателей средств индивидуализации и органов исполнительной власти за умышлен- ную регистрацию фирменного наименования, товарного знака и знака обслуживания схожего до степени смешения, с зарегистрированными раннее средствами индивидуализации;

- юридической ответственности за использование фирменного наименования, товарного знака и знака обслуживания тождественного с другими средствами индивидуализации.

В настоящее время в России, как и в других странах мира средства индивидуализации являются связывающим звеном между изготовителем и покупателем, промышленностью и торговлей, производителем и потребителем. Средства индивидуализации способствуют обороноспо- 
собности товаров и являются в какой-то степени рекламой ${ }^{1}$.

Правовой режим фирменного наименования, товарного знака и знака обслуживания в России предусмотрен административным, гражданским и уголовным законодательством. В гражданском законодательстве раскрываются только вопросы субъектного состава, структуры и охраны исключительного права на фирменное наименование, товарный знак и знак обслуживания, но не содержится мер ответственности за нарушения, связанные с использованием указанных средств индивидуализации.

К источникам административного права, регулирующим режим средств индивидуализации организаций, товаров, работ и услуг, можно отнести Федеральные законы «0 регистрации юридических лиц и индивидуальных предпринимателей» ${ }^{2}$, «О защите конкуренции» ${ }^{3}$, Кодекс Российской Федерации об административных правонарушения ${ }^{4}$ (далее КоАП РФ) и др. К источникам уголовного права - Уголовный кодекс РФ 5 .

Правовой механизм обеспечения защита фирменного наименования, товарного знака и знак обслуживания представляет собой совокупность правовых средств, определенных в теории административного права и законодательстве об административных правонарушениях как способы правовой защиты исключительного права на указанные средства индивидуализации. Существуют особые группы отношений, которые возникают,

\footnotetext{
1 Клейменова М.О. Административно-правовые методы государственного регулирования по обеспечению режима фирменного наименования и его правообладателя. Диссертация на соиск. уч. ст. к.ю.н. по специальностям 12.00.03. и 12.00.14. M. 2011.

2 Федеральный закон от 08.08.2001 №129-Ф3 (ред. от 21.07.2014) «О государственной регистрации юридических лиц и индивидуальных предпринимателей» (с изм. и доп., вступ. в силу с 30.09.2014) // «Собрание законодательства РФ». 13.08.2001, № 33 (часть I), ст. 3431.

3 Федеральный закон от 26.06.2006 135- Ф3 (ред.от 04.06.2014, с изм. от 21.07.2014) //»Собрание законодательства РФ», 31.07.2006, N 31 (1 ч.), ст. 3434.

4 Кодекс Российской Федерации об административных правонарушениях" от 30.12.2001 N 195-Ф3 (ред. от 21.07.2014) (с изм. и доп., вступ. в силу с 06.08.2014) // «Собрание законодательства РФ», 07.01.2002, № 1 (ч. 1), ст. 1.

5 Уголовный кодекс Российской Федерации” от 13.06.1996 N 63-Ф3 (ред. от 21.07.2014) (с изм. и доп., вступ. в силу с 04.08.2014) // «Собрание законодательства РФ», 17.06.1996, № 25 , ст. 2954.
}

изменяются и прекращаются только в результате властно организующей деятельности государства. Возникнув без определенного фактического (материального) содержания, юридическая форма обретает затем это содержание (совершаются положительные действия), тем самым достигается цель правового регулирования - складываются в полном объеме фактические отношения, которых раньше не было 6 .

Общественные отношения по обеспечению режима фирменного наименования, товарного знака и знака обслуживания и их правообладателей также возникают, изменяются и прекращаются в результате властно организующей деятельности государства. Так, только вследствие регистрационных действий Федеральной налоговой службы Российской Федерации (ФНС России) (внесении записи в ЕГРЮЛ) у коммерческой организации возникает исключительное право на фирменное наименование. Вследствие регистрационных действий Федеральной службы по интеллектуальной собственности (Роспатент) у юридических лиц и индивидуальных предпринимателей возникает исключительное право на товарный знак и знак обслуживание, но данное право ограниченно сроком действия, т.к. свидетельство о государственной регистрации товарного знака и знака обслуживания выдается на 10 лет.

Административно-правовой режим средств индивидуализации юридических лиц, товаров, работ и услуг является специальным комплексом оперативных управленческих решений и административных правовых методов, которые выражаются в установлении правил создания, существования и прекращения коммерческой организации.

Комплекс императивных методов правового регулирования определяет административно-правовое регулирование режима фирменного наименования, товарного знака и знака обслуживания, которое выражается в регистрационном и ликвидационном режиме фирменного наименования, в регистрационном режиме товарного знака и знака обслуживания, ответственности за незаконное использование средств индивидуализации, особенности разрешения споров о нарушениях исключительных прав на средства индивидуализации.

При создании средств индивидуализации не все предприниматели учитывают их различия, ча-

6 Шейхов Т.С. Указ. соч. С. 47. 
сто в качестве фирменного наименования юридического лица регистрируется товарный знак, принадлежащий другим лицам, получившим право на этот товарный знак ранее регистрации юридического лица.

При защите исключительных прав на средства индивидуализации (фирменное наименование, товарный знак, знак обслуживания), тождественные или сходные до степени смешения, преимущество имеет средство индивидуализации, исключительное право на которое возникло ранее.

Законодательство об административных правонарушениях содержит санкции за незаконное использование товарного знака, знака обслуживания, оставляя без внимания фирменное наименование. При рассмотрении судебной практики по вопросам о нарушениях исключительного права на фирменное наименование и на другие средства индивидуализации, такие как товарные знаки, знаки обслуживания, отслеживается прецедент, из которого следует, что суд, рассматривая подобные споры, анализирует признак идентичности средств индивидуализации спорящих сторон, а в случаях, когда средства индивидуализации являются идентичными, исходит из принципа старшинства, т.е. из даты регистрации. Арбитражные суды, рассматривая споры между правообладателей разных средств индивидуализации (например, фирменное наименование и товарный знак), несмотря на то, что эти средства индивидуализации являются идентичными, в удовлетворении исков отказывают.

В КоАП РФ и других законодательных актах не содержатся средств защиты исключительного права на фирменное наименование, в связи с чем правообладателем приходится использовать средства самозащиты и включать фирменное наименование в товарный знак или другие средства индивидуализации. Необходимо дополнить КоАП РФ мерой ответственности за правонарушения, связанные с незаконным использованием чужого фирменного наименования или незаконное использование в фирменном наименовании чужого товарного знака, знака обслуживания или коммерческого обозначения.

В определении путей совершенствования административно-правового регулирования защиты исключительного права на фирменное наименование, товарный знак и знак обслуживания, необходимо выделить следующее.

1. При рассмотрении споров о нарушении исключительного права на фирменное наи- менование и другие средства индивидуализации (товарные знаки, знаки обслуживания и др.), суды анализируют признак идентичности средств индивидуализации спорящих сторон. В тех случаях, когда эти средства индивидуализации являются идентичными, суды исходят из принципа старшинства, т.е. из даты регистрации. Чаще всего арбитражные суды, рассматривая споры между правообладателями разных средств индивидуализации (например, фирменное наименование и товарный знак), несмотря на то что эти средства индивидуализации являются идентичными, в удовлетворении исков отказывают.

2. В административном законодательстве отсутствуют способы защиты исключительного права на фирменное наименование. Это приводит к тому, что субъекты исключительного права на фирменное наименование чаще используют судебный способ защиты, избегая при этом административный. В порядок рассмотрения споров о нарушении исключительного права на фирменное наименование целесообразно внести дополнения - досудебный порядок урегулирования споров. Органом, осуществляющим досудебное урегулирование споров, должна стать Федеральная антимонопольная служба Российской Федерации (далее - ФАС России).

3. В соответствии со ст. 22 Федерального закона «О защите конкуренции» антимонопольный орган осуществляет контроль над соблюдением антимонопольного законодательства, выявляет нарушения антимонопольного законодательства, предотвращает недобросовестную конкуренцию и т.д. К видам недобросовестной конкуренции относится использование чужого фирменного наименования, товарного знака и коммерческого обозначения. ФАС России дожжен рассматривать споры о незаконном использовании фирменного наименования или споров по сходству фирменных наименований до степени смешения с другими средствами индивидуализации.

4. Анализ правоприменительной практики свидетельствует о необходимости усиления контроля и надзора со стороны государства за законностью использования фирменного наименования, товарного знака и знака обслуживания. Функции по контролю и надзору за законностью использования средств индивидуализации должны быть возложены на территориальные специализированные органы исполнительной власти. 


\section{Библиография:}

1. Гражданский кодекс Российской Федерации (часть четвертая)" от 18.12.2006 № 230-Ф3 (ред. от 23.07.2013) (с изм. и доп., вступающими в силу с 01.09.2013) // «Собрание законодательства РФ», 25.12.2006, № 52 (1 ч.), ст. 5496.

2. Кодекс Российской Федерации об административных правонарушениях от 30.12.2001 №195-Ф3 (ред. 0т 21.07.2014) (с изм. И доп., вступ. В силу с 06.08.2014)// «Собрание законодательства РФ», 07.01.2002, №1, (ч.1). ст.1.

3. Уголовный кодекс Российской Федерации" от 13.06.1996 N 63-ФЗ (ред. от 21.07.2014) (с изм. и доп., вступ. в силу с 04.08.2014) // «Собрание законодательства РФ», 17.06.1996, № 25, ст. 2954.

4. Федеральный закон от 08.08.2001 №129-Ф3 (ред. от 21.07.2014) «0 государственной регистрации юридических лиц и индивидуальных предпринимателей» (с изм. и доп., вступ. в силу с 30.09.2014) // «Собрание законодательства РФ». 13.08.2001, № 33 (часть I), ст. 3431.

5. Федеральный закон от 26.06.2006 135-Ф3 (ред.от 04.06.2014, с изм. от 21.07.2014) //»Собрание законодательства РФ», 31.07.2006, N 31 (1 ч.), ст. 3434.

6. Апряткина Г.С. Актуальные проблемы защиты интеллектуальной собственности, судебная практика Федерального арбитражного суда Волго-Вятского района. URL: www.arbitr.ru.

7. Головкин В. Столкновение прав владельцев торговых знаков и фирменного наименования // Рос. аптеки. 2006. № 6. С. 8-9.

8. Клейменова М.О. Административно-правовые методы государственного регулирования по обеспечению режима фирменного наименования и его правообладателя. Диссертация на соиск. уч. ст. к.ю.н. по специальностям 12.00.03. и 12.00.14. М. 2011.

9. Шейхов Т.С. Административная ответственность юридического лица за нарушение налогового законодательства. // Дис. на соис. уч. степени к.ю.н. 12.00.14. М. 2008.

10. К. В. Лиджеева Средства индивидуализации и их правовая охрана // Право и политика. - 2012. - 4. - С. 780 - 787.

11. Беляева Г.С. К вопросу о понятии правового режима // Административное и муниципальное право. - 2014. - 3. - С. 272 - 285. DOI: 10.7256/1999-2807.2014.3.10938.

12. Трегубова Е.В. Дозволения и запреты как методы (средства) административного регулирования в российском праве // Административное и муниципальное право. - 2013. - 10. - С. 986 - 997. DOI: 10.7256/19992807.2013.10.9673.

\section{References (transliterated):}

1. Grazhdanskii kodeks Rossiiskoi Federatsii (chast' chetvertaya)" ot 18.12.2006 № 230-FZ (red. ot 23.07.2013) (s izm. i dop., vstupayushchimi v silu s 01.09.2013) // «Sobranie zakonodatel'stva RF», 25.12.2006, № 52 (1 ch.), st. 5496.

2. Kodeks Rossiiskoi Federatsii ob administrativnykh pravonarusheniyakh ot 30.12.2001 №195-FZ (red. Ot 21.07.2014) (s izm. I dop., vstup. V silu s 06.08.2014)// «Sobranie zakonodatel'stva RF», 07.01.2002, №1, (ch.1). st.1.

3. Ugolovnyi kodeks Rossiiskoi Federatsii" ot 13.06.1996 N 63-FZ (red. ot 21.07.2014) (s izm. i dop., vstup. v silu s 04.08.2014) // «Sobranie zakonodatel'stva RF», 17.06.1996, № 25, st. 2954.

4. Federal'nyi zakon ot 08.08.2001 №129-FZ (red. ot 21.07.2014) «0 gosudarstvennoi registratsii yuridicheskikh lits i individual'nykh predprinimatelei» (s izm. i dop., vstup.v silu s 30.09.2014) // «Sobranie zakonodatel'stva RF». 13.08.2001, № 33 (chast' I), st. 3431 .

5. Federal'nyi zakon ot 26.06.2006 135-FZ (red.ot 04.06.2014, s izm. ot 21.07.2014) //»Sobranie zakonodatel'stva RF», 31.07.2006, N 31 (1 ch.), st. 3434.

6. Apryatkina G.S. Aktual'nye problemy zashchity intellektual'noi sobstvennosti, sudebnaya praktika Federal'nogo arbitrazhnogo suda Volgo-Vyatskogo raiona. URL: www.arbitr.ru.

7. Golovkin V. Stolknovenie prav vladel'tsev torgovykh znakov i firmennogo naimenovaniya // Ros. apteki. 2006. № 6. S. 8-9.

8. Kleimenova M.O. Administrativno-pravovye metody gosudarstvennogo regulirovaniya po obespecheniyu rezhima firmennogo naimenovaniya i ego pravoobladatelya. Dissertatsiya na soisk. uch. st. k.yu.n. po spetsial'nostyam 12.00.03. i 12.00.14. M. 2011.

9. Sheikhov T.S. Administrativnaya otvetstvennost' yuridicheskogo litsa za narushenie nalogovogo zakonodatel'stva. // Dis. na sois. uch. stepeni k.yu.n. 12.00.14. M. 2008.

10. K. V. Lidzheeva Sredstva individualizatsii i ikh pravovaya okhrana // Pravo i politika. - 2012. - 4. - C. 780 - 787.

11. Belyaeva G.S. K voprosu o ponyatii pravovogo rezhima // Administrativnoe i munitsipal'noe pravo. - 2014. - 3. - C. 272 285. DOI: 10.7256/1999-2807.2014.3.10938.

12. Tregubova E.V. Dozvoleniya i zaprety kak metody (sredstva) administrativnogo regulirovaniya v rossiiskom prave // Administrativnoe i munitsipal'noe pravo. - 2013. - 10. - C. 986 - 997. DOI: 10.7256/1999-2807.2013.10.9673. 